\title{
A Research Review on Theme Park
}

\author{
Guanglin $\mathrm{Hu}^{1}$ \\ ${ }^{1}$ Management School, Shanghai University of Engineering and Science, China \\ Correspondence: Guanglin Hu, Management School, Shanghai University of Engineering and Science, China. \\ E-mail: kwanglim@126.com
}

Received: November 14, 2013

Accepted: December 11, 2013

Online Published: December 12, 2013

doi:10.5430/bmr.v2n4p83

URL: http://dx.doi.org/10.5430/bmr.v2n4p83

\begin{abstract}
The theme park is a creative garden tour clues which is built in order to meet the demand of tourists diversified entertainment and the modern tourist destination formation of planning activities. Under the background of the creative economy, theme park is a tourism economy complex syncretizing creative elements. According to the World Tourism Organization (WTO) predicted, theme park is one of the three trends of the development of international tourism right now and in the future. With the Disneyland settled down in Shanghai, the theme park become the most talked topic of whole world and the academic research focus once again. Through consulting a large number of literature at home and abroad, the paper elaborates the industry mainly from the historical evolution and classification of the theme park, diversity, space layout and industry linkage. And the paper points out the future development of the theme park, which has guiding significance for the further study of the theme park.
\end{abstract}

Keywords: Theme park, Disney, Classification, Diversity, Space layout

\section{The introduction}

In modern significance, the theme park as a new developing form of rising tourism industry, appeared in 1950s in the United States. The Disneyland created by Walt Disney's in the southern California, is the first theme park in the word with modern meaning. It abandoned the single mechanical nature of the amusement park, created the theme of the park and made visitors feel personally on the scene which forming a coherent and abundant experience with running through the mainline. The theme park industry in China is growing up with Shenzhen Splendid China opened for business in September 1989. Splendid China has achieved favourable economic effectiveness and social benefits and promoted the construction of theme parks in China. At the same time, it has pushed the theme park as a new way of tourism into the whole country. With the Disneyland settled down in Shanghai, the theme park become the most talked topic of whole world and the focus of academic research once again.

\section{The research review on the definition and the historical evolution of theme park}

Research on the theme park abroad originated from the 1970s. China began the research in the late 80s and prevailed in 90s. Throughout the domestic and foreign research, theme park is substantially a kind of man-made landscape. It focuses on a specific theme and set many entertainment contents, leisure elements and service facilities in the integrated. The form of theme park is diverse. Meanwhile its primary purpose is making profits (Chris cooper, 1994; Xiangpin Zhou, 1995; Jiajun Lou, 1998; Zhimin Ma, 1999; Guanzhi Dong, 2000). Theme park is the result of European amusement park (Brown and Church, 1987). Disneyland which opened in 1955 in California in the United States is marked as the birth of the world's first theme park (Richard, 1987). The development of theme park in Japan started relatively the earliest in Asia (Shi Qi ZhaoShi, 1991). There are two theories (Jiajun Lou, 1998) and the syllogism (Liming Zhang, 2007) about the development of theme park in China. It generally has experienced the progress from the initial single static displaying to making tourists enjoy a comprehensive participation experience in interactive way and making theme park merge together with high technology. Many scholars think, life cycle theory is applicable to the rise and substitute of the theme park. Theme park also experiences the progress of resource discovery, swift growth, steady development and decline or recovery (Bulter R.W., 1980). Operators use artificial methods to exert influence on marketing campaign in order to extend the life cycle of the market competition.

\section{The research review on the classification of the theme park}

\subsection{According to the size, project characteristics and service radius}

The vice President of European association for the theme park (Chris Yoshii) think, according to the scale of the 
theme park, the project characteristics and service radius of the theme park it will be divided into the following several types: (1) Large theme park. The numbers of tourists every year is more than 5 million. Tourists markets are the national market and international market. There are distinct themes, main brand appeal which was made up of multiple parts, a comfortable travel accommodations which mainly provide participatory entertainment projects and investment of $\$ 1$ billion, such as Disneyland, Universal Studios, etc. (2) Regional theme park. The numbers of tourists every year is from 1.5 million to 3.5 million. There are a certain theme routes and acting. On the project settings, ornamental static landscape is given priority. There are potential brands. Tourist markets are the market in the province and neighboring markets. The investment of it is about $\$ 200$ million. (3) Theme park. The numbers of tourists every year is from 1 million to more than 2 million. It is situated around the city. Tourist market is mainly the city market. It mainly provides mechanical participatory rides. The theme is single and the influence of its brand is limited. The investment is from $\$ 80$ million to $\$ 100$ million. (4) Small theme parks and attractions. The numbers of tourists every year is from below 200000 to 200000 . It is located in the city and indoor or outdoor. The tourists stay shorter. Its mainly small single subject is static artificial landscape. Tourist market is the city market, sometimes it can achieve the whole city. The investment is from 30 million to $\$ 80$ million.

Combined with the actual situation of our country, we will regard the theme park which was invested $¥ 250$ million and covers an area of more than 25 hectares scale as the major theme park. Meanwhile we will regard the theme park which was invested from $¥ 50$ million to $¥ 100$ million and covers a smaller area as small theme park.

\subsection{According to the nature of the subject of theme park}

(1) Miniature landscape classes. According to a certain proportion, the exotic foreign famous buildings, ancient and modern attractions was zoomed out in construction in order to let the tourists quickly appreciate different cultures.

This kind of theme park set a precedent in China, such as "Splendid China", Shenzhen Window of the World and so on.

(2) The customs class. The content of the theme park is mainly showing our folk customs which performance for simulation and represent the national life scenes and folk customs at most. It has higher participation, such as Shenzhen China Folk Village, etc.

(3) The historical and cultural class. This kind of theme park is on the background of splendid culture of the Chinese nation. Generally it is a historical era scene or simulated with literary classics as the theme of two types, such as the Grand View Garden, Journey to the Palace, Tang City, Song City, etc.

(4) Theme parks. According to tourism preference of pleasure, difference following the experience economy era, some new tourist theme amusement places are established. This theme forms with modern high technology as the background, more like Shenzhen Happy Valley, Suzhou Park, etc.

(5) The plants class. Animals and plants are as the theme, including the theme zoo all over the world, botanical gardens and various aquarium, etc.

(6) The film class. The planning conception of this kind is themed by scene, film, television shooting TV and movies. It is the combination of tourism products, film and television shooting classic. It sets ornamental and practical at an organic whole, such as West Film Studio, Hengdian World Studios, Wuxi Zhenbeibao Studio, etc.

\section{3 other classification methods}

According to the location of theme park it can be divided into city theme park, theme park, suburbs village theme parks, beach theme park, traffic corridor types such as theme parks.

According to the main functions of the theme park, it can be divided into the static landscape type of theme park, dynamic landscape type of theme park, performing arts theme park, activity participation theme park, project challenging theme park and other types.

According to the new and high technology content of the theme park it can be divided into traditional technology (mainly mechanical technology) theme park, modern technology (mainly electronic technology) theme park, high and new technology (in network technology, digital technology, virtual reality technology is given priority to) theme park and other types.

According to the theme park development stage, some scholars also divide the theme park into four generations. The first generation of relying on natural resources, the second generation paying attention to urban entertainment, the third generation is given priority to with simulation, miniature landscape, the fourth generation of theme park which is mainly based on three-dimensional, four-dimensional, animation, science and technology. 


\section{The research review on the diversity of theme park}

The success of the Disneyland and universal studios is that they put the movie link transplantation in the theme park, use high technology to realize virtual landscape and reduction of various film scene, use advanced technology to create all sorts of virtual scene and attract visitors of all sorts of different ages all over the world. Their common practice is to use their new films to develop new projects. There are more than 130 new entertainments and theme performances in Disney from 1955 to 1999.

In addition, according to the needs of market constantly they also develop new series of theme park. Theme park in China experiences progress from mainly transplanting and imitating of the single topic structure to multiple thematic structure and comprehensive development. Given priority to local culture, entertainment and education as a representative of the theme park there are the Suzhou Paradise, Yunnan Kunming Expo Garden, Kaifeng Millennium City Park. At the same time, the theme parks which are based on high-tech agriculture theme parks are also booming.

\section{The research review on the space layout and influence factors analysis of theme park}

There are many factors that can affect large city theme park layout. Different scholars have different views, but they generally use the time distance and hinterland population size as a measure of location selection. The Urban Land Institute in Washington D.C. in the United State concluded that as a large theme park the first level of tourism market need at least a population of 2 million (at $80 \mathrm{~km}$ or within $1 \mathrm{~h}$ range of driving from distance), the secondary level of market also should need more than 2 million people (at $240 \mathrm{~km}$ or $3 \mathrm{~h}$ range of driving distance), level 3 customers cannot rely too much on the secondary market. At the same time the institute points out five important factors to consider of the theme park land location which are that it is located beside the main trunk or nearby, the line of sight is open, there is plenty of water, electricity, sewage treatment facilities, the residents nearby don't mind and there are plenty of lands. Britain's national tourism administration has proposed the ideal of the theme park location must meet four conditions which was that in $2 \mathrm{~h}$ driving range there is a population of 12 million or less than $1 \mathrm{~h}$ from big tourist resorts, it must be near two commercial concentration areas, it compared with other theme parks adjacent at best and it is within 15 minutes according to the main road traffic.

Luiz (1996) use the project, such as accessibility, regional population, climate conditions, infrastructure conditions, land reserves, the location of the available labor force as a theme park project evaluation index. Curren (1990) argues that in the process of the location of the project, we should consider mainly land cost of the project and other related costs, functional needs, profitability and other factors.

Domestic scholars, the major factors that affect the layout of the theme park include tourist market conditions, traffic conditions, regional development level, city tourism image perception, spatial agglomeration and competition, decision makers behavior (including the decision-making behavior of investors, government decision-making behavior) (Jigang Bao 1997; Bihu Wu, 2006), etc. Theme parks are built in order to meet the demand of tourists diversified entertainment a sexual garden clues and planning the activities creative way form of modern tourism destination (Guanzhi Dong, 2000). Under the background of the creative economy, theme park is a tourism economy complex syncretizing creative elements. According to the World Tourism Organization (WTO) predicted, theme park is one of the three trends of the development of international tourism right now and in the future. Accompany the Disneyland settled down in Shanghai, the theme park become the most talked topic of whole world and the academic research focus once again. The Urban Land Institute in Washington D.C. In the United States, the geographical location of large scale theme park is the key to success. Therefore, the research on time-space layout of theme park has great practical significance.

\section{The research review on contact related to the theme park industry}

In foreign countries, the development of the tourist area for urban planning and regional zoning plays an important role. Urban area of regional economic development to a certain extent determines the development of tourism. Tourism is regarded as the leading industries, or only the different development model as an affiliated industry, in different extent influence the development of theme parks in the future. Malcolm Cooper studied how to use the theme park to attract tourists, the theme park by extending the existing tourism products, senior residential development within the park, to make up for the usual expenses, these improvements for the tourism development of Harvey bay provides a good opportunity. Peter Dybedal mainly research the role of the theme park for tourism development in remote, selection of Norway's four theme park as a case study (3 is located in rural areas), and a detailed description and analysis of the theme park tourist structure, theme activity characteristics of the geographical location and the main function. The paper finally summarizes the economic influence of theme park and think successful theme parks have a great contribution to regional tourism. 
Domestic scholars study systematically on the formation of the theme park industry agglomeration, pattern of development of creative industry. Yabing Li (2007) put forward the theme park spatial economic structure is mainly composed of theme tourism clusters around space structure and the structure of land use spatial structure and layout of the formats. He thought theme park tourism passenger flowing directly results in the formation of theme park cluster and indirect influence theme park surrounding area forms agglomeration and real estate prices rise. Jingfeng Chu (2008) analyzed the brand advantage of the big four spatial agglomeration Hollywood film and television creative industry. She put forward the internal regularity of creative industry management. On the basis of the comb type, film and television theme park roots. Wen Guo(2008) analyzed the development and tourism development of "symbiosis" operation mode of Wuxi Film Base. Wei Li(2010) analyzed theme parks in the pearl river delta industrial cluster evolution mechanism analysis and development model.

\section{The theme park development trend and the research direction at home and abroad}

With the expansion of globalization and development of the theme park, theme park in the world has entered the homogeneity competition period, especially the construction of the Disney theme park in the global scope. It brings many problems, such as the mimic of the same type theme park, a lack of new idea, etc. The theme park is located and constructed according to the local cultural tradition. Because of the difference of Chinese and western culture, the cultural and the construction of theme park are different. Meanwhile, there are significant differences with tourism vacation system between foreign countries and China. The difference of research progress, living habits, values, hard and soft facilities makes the direction of domestic and foreign theme park development also differ. However, as one of the important development direction of tourism development, theme park must develop toward the general trend of sustainability, ecological features, innovativeness and cultural.

Disney's success lies in the transfer of the film part in the theme park and the use of technology to realize virtual landscape and reduction of various film scene. It makes the tourists find pleasure in it and realize the experience of a fairy tale dream in the heart. So it successfully implement the branding management, proprietary business and part of the core product differentiation strategy of outsourcing. With high-tech products into the direction of the construction of theme park and take this opportunity to broaden the theme park marketing channels, enhance participation and entertaining visitors, which is one of the research direction of the theme park development abroad.

The theme park in China mostly located in big cities such as Shenzhen, Beijing, Chengdu, Shanghai. Except the tourism development of "travel + real estate" model, basically it is given priority to with individual development. So it lacks community development and cultural construction. And the frequent infrastructure safety accidents caused negative influence in the development and publicity of theme parks. It is necessary to improve the quality of service and training in the scenic area. It should be prolong the lifecycle of the theme park, theme park development sustainability based on the hardware, software, cultural services and science and technology innovation in the future.

\section{References}

Bihu Wu, Xi Yu, Ning Dang. China theme park scenic area development situation analysis - based on the national A level scenic spots (points) statistics. Journal of Geography and Geographic Information Science, 2006, 22 (1) : 89-93.

Bulter R.W. The concept of a tourist area cycle of evolution: implication for management of resources. Canadian Geogerapher, 1980,(24):5-12.

Chunshen Li. China theme park development present situation and innovation. Journal of Geographical Research and Development, 2007, 2 (26) : 71-74.

Current J, Min H, Schilling D. Multi-objective analysis of facility location decisions. European Journal of Operational Research, 1900(49):295-307.

Gigang Bao. (1997). The influence factors of theme park development system analysis. Journal of Geographical, 1997,52 (3) : 237-245.

Guanzhi Dong. (2000). Tourism theme park management theory and practice. Guangzhou: Guangdong Tourism Publishing House.

Guo Cui, Jingfeng Chu etc. (2011). Creative tourism connotation abroad study. Journal of Human Geography, 2011 (6) : 24-33.

Ishizaki Hajime-shi, OtoAkiramaru, Guo Shengfa. (1991). Theme park in Japan. Gardening Quarterly (Taiwan), 1991. 
JiaJun Lou. (1998). Try to talk about the theme park in China. Journal of Guilin Tourism College, 9 (3): 47-51.

Jigang Bao. (1994). The study on the large theme park layout preliminary. Journal of geographical research, 1994, $13(3): 83-89$.

Jingfeng Chu. (2008). Disney took a worldwide network of creative industrialization strategy management. Journal of World Geography Research, 2008 (4) : 115-125.

John Brown \& Ann Church. (1987). Theme Parks in Europe. Tourism Analyst. February, 1987.

Liming Zhang. (2007). Analysis of space and time and the factors affecting the ocean theme parks in China. Journal of Travel Journal, 2007 (4): 67-72.

Luiz M, Bruce C, Paulo R. (1996). Expert. Systems in Tourism Marketing. Routledge.

Malcolm Cooper. (2001). The development of tourism in a new urban environment: Using a theme park to re-establish tourist flows to the city of Harvey Bay. Travel and Tourism Analyst, 2001(2):45.

Michael Sorkin. (1993). Variations on a theme park: the new American city and the end of public space, The Noonday Press, New York, NY.

Peter Dybedal. (2000). Theme park as a Flagship Attraction in Peripheral Areas. Annals of Tourism Research, 2000(27):250-252.

Richard Lyon. (1987). Theme Parks in US. Travel and Tourism Analyst. January, 1987.

Richards, G. \& C. Raymond. (2000). Creative tourism. ATLAS news, 2000(23):16-20.

S. Anton Clave. (2010). The Global Theme Park Industry. CABI. UK.

Sara Nordin. (2006). Tourism Clustering \& Innovation-Paths to Economic Growth \& Development [EB/OL]. [Online] Available: http://www.etour.se,2006-12-21.

Smart J.E. \& Casazza J.A. (1989). Recreational Development Handbook. ULI: the Urban Land Institute.

Wei Li. (2010). Theme parks in the pearl river delta industrial cluster evolution pattern analysis. Journal of District Economy, 2010 (1): 31-32.

Wen Guo \& Li Wang. (2008). The film and television theme park tourism development mode of "symbiosis" research and industrial communities demands. Journal of travel, 2008, 4 (23): 64-71.

Yabing Li. (2007). Theme park tourist passenger space economic effect analysis. Industrial Observations, 2007 (34) : 88-89.

Zhimin Ma. (1999). Some views of China's theme park development. China Tourism News. 1999 (1): 17-19. 